\title{
ALUR DAN KARAKTER \\ DALAM NOVEL DEKAT DAN NYARING (2019) KARYA SABDA ARMANDIO
}

\author{
Dita Christina \\ Universitas Sebelas Maret Surakarta \\ ditachristina@stundent.uns.ac.id
}

\begin{abstract}
Abstrak
Penelitian ini mengkaji tentang unsur-unsur dalam novel Dekat dan Nyaring (2019) karya Sabda Armandio dengan menggunakan kajian struktural. Permasalahan dalam penelitian ini adalah unsur-unsur dari fakta cerita yang meliputi: i) alur; ii) karakter; iii) hubungan alur dan karakter. Tujuan penelitian ini adalah: i) mendeskripsikan alur dalam novel Dekat dan Nyaring; ii) mendeskripsikan karakter dalam novel Dekat dan Nyaring; iii) mendeskripsikan hubungan alur dan karakter dalam novel Dekat dan Nyaring. Metode yang digunakan dalam penelitian ini adalah metode deskriptif kualitatif dengan menggunakan pendekatan struktural Robert Stanton. Objek material penelitian ini adalah novel Dekat dan Nyaring, sedangkan objek formal penelitian ini adalah unsur-unsur yang meliputi alur, karakter, serta hubungan alur dan karakter. Sumber data dalam penelitian ini adalah novel Dekat dan Nyaring karya Sabda Armandio. Data berupa teks naratif dalam novel Dekat dan Nyaring. Hasil penelitian terhadap novel Dekat dan Nyaring karya Sabda Armandio adalah: i) alur yang digunakan dalam novel Dekat dan Nyaring merupakan alur campuran; ii) karakter sentral dalam novel Dekat dan Nyaring yaitu Anak Baik, sedangkan karakter utamanya yaitu Edi dan Nisbi; iii) alur dan karakter saling berhubungan dan paling erat kaitannya dalam membangun keseimbangan cerita.
\end{abstract}

Kata-kata kunci: fakta cerita, alur, karakter

\begin{abstract}
This study examines the elements in Dekat dan Nyaring novel (2019) by Sabda Armandio using structural studies. The problems in this study are elements of the story facts which include: i) plot; ii) character; iii) plot and character relationships. The objectives of this study are: i) describe the plot in Dekat dan Nyaring novel; ii) describe the characters in Dekat dan Nyaring novel; iii) describe the relationship between the plot and character in Dekat dan Nyaring novel. The method used in this study is a qualitative descriptive method using Robert Stanton's structural approach. The object of this research material is Dekat dan Nyaring novel, while the formal object of this study are the elements which include plot, character, and the relationship between plot and character. The data source in this study is Dekat dan Nyaring novel by Sabda Armandio. The data are in the form of narrative texts in Dekat dan Nyaring novel. The results of the study of Dekat dan Nyaring novel by Sabda Armandio are: i) the plot used in Dekat dan Nyaring novel is a mixed plot; ii) the central character in the Dekat dan Nyaring novel is Good Children, while the main characters are Edi and Nisbi; iii) the plot and characters are interconnected and most closely related in building the balance of the story.
\end{abstract}

Keywords: story facts, plot, characters

\section{PENDAHULUAN}

Novel adalah salah satu jenis karya sastra yang bersifat fiksi dan penuh dengan imajinasi. Novel tidak terbentuk dengan sederhana, melainkan tersusun 
dari unsur-unsur yang saling berkaitan. Hal tersebut tidak terlepas dari diri pengarang. Seorang pengarang tidak dapat terlalu berharap pembaca karyanya adalah orang yang terlatih secara khusus. Situasi semacam itu menandakan bahwa karya sastra seharusnya dapat bercerita dengan sendirinya (Stanton, 2012: 1).

Mereduksi sastra dan seni-seni lain ke dalam kategori-kategori sama saja dengan mendistorsi dan menggampangkan subjek-subjek yang ada padanya; sastra bersifat fleksibel, subtil, dan majemuk. Setiap karya yang berhasil merupakan satu individu unik karena sebenarnya tidak ada seorang pun yang bisa menguraikan sebuah organisme secara menyeluruh (Stanton, 2012: 20). Apa yang telah dijelaskan melalui pengistilahan singkat menyangkut adanya strukturstruktur dalam karya sastra yang tersusun menjadi sebuah kesatuan harmonis. Penelitian terhadap struktur-struktur tersebut akan mengungkap adanya fakta cerita, tema, dan sarana-sarana sastra dalam sebuah karya sastra yang dalam hal ini berupa novel.

Novel Dekat dan Nyaring (2019) yang ditulis oleh Sabda Armandio menceritakan tentang kehidupan penghuni Gang Patos, sebuah kampung yang berbatasan dengan sungai. Selama kurun waktu sehari, berbagai macam peristiwa telah terjadi. Kisah berawal dari kehidupan seorang karakter bernama Edi. Ia adalah seorang penjual daging ular dan warung kelontong di seberang sungai Gang Patos. Edi memiliki keinginan kuat untuk menyamai sistem kerja sebuah minimarket yang buka 24 jam sehari sehingga ia mewawancarai manajer walaupun sebelumnya sempat diusir oleh satpam. Cerita tidak berhenti menceritakan tentang kehidupannya saja, melainkan interaksinya dengan tokohtokoh lain, seperti Idris, Kina, Nisbi, Wak Eli, Sam, Anak Baik, Aziz, dan yang lainnya. Meskipun karakter Edi muncul di awal cerita, Anak Baiklah yang menjadi karakter sentralnya. Banyak hal yang tidak terduga dalam novel ini.

Unsur-unsur dalam novel yang saling berkaitan merupakan alasan penulis memilih novel Dekat dan Nyaring (2019) sebagai objek kajian penelitian. Pendekatan struktural Robert Stanton menjadi teori yang tepat digunakan untuk menganalisis novel Dekat dan Nyaring (2019). Penelaahan tersebut meliputi alur, karakter, serta hubungan antara keduanya.

Penyebutan istilah sastra untuk suatu tulisan memang dapat dimengerti melalui intuisi masing-masing manusia. Namun, kenyataannya batasan-batasan yang diberikan pada sebutan sastra tersebut sering luput dari tangkapan ketika menelaahnya lebih lanjut. Maka dari itu, permasalahan yang ada dapat dipahami berdasarkan pendekatan-pendekatan terdahulu (Teeuw, 1984: 21-22).

Pengertian istilah sastra dapat diruntut dari istilah dalam bahasa Sanskerta, yaitu akar kata śās-, jika diartikan dalam kata kerja turunan berarti 'mengarahkan, mengajar, memberi petunjuk atau instruksi'. Akhiran berupa -tra merujuk pada alat atau sarana. Berdasarkan asal kata tersebut, sastra diartikan sebagai alat untuk 
mengajar, buku petunjuk, buku instruksi atau pengajaran. Namun, hal tersebut belum sepenuhnya mengartikan batasan dari sastra (Teeuw, 1984: 23).

Cara lain untuk memberikan definisi pada sastra adalah dengan membatasinya pada mahakarya. Mahakarya yang dimaksud merujuk pada bukubuku yang dianggap menonjol dalam hal ekspresi sastranya. Kriteria yang digunakan sebagai tolok ukur adalah dari segi estetis. Jika ada keilmiahan di dalamnya, maka tetap dikombinasikan dengan nilai estetis (Wellek, 1993: 12).

Menurut teori struktural Robert Stanton terdapat tiga topik yang disertakan dalam penerapan metode penelitian terhadap fiksi serius, yaitu faktafakta, tema, dan sarana-sarana sastra (Stanton, 2012: 20). Fakta-fakta yang selanjutnya disebut dengan fakta cerita akan dibahas dalam penelitian ini. Subtopik dibatasi pada alur, karakter, dan juga hubungan antara keduanya sebab alur dan karakter memiliki hubungan yang paling erat sebagai unsur-unsur yang membangun sebuah cerita.

Karakter dan alur merupakan bagian dari fakta cerita. Elemen-elemen ini berfungsi sebagai catatan kejadian imajinatif dari sebuah cerita (Stanton, 2012: 22). Alur dan karakter yang terdapat dalam sebuah struktur cerita harus masuk akal. Masuk akal yang dimaksudkan bukanlah masuk akal dari segi kebenaran cerita. Namun, hal tersebut berkaitan dengan konsistensi jalannya cerita yang dipaparkan.

Secara umum, alur merupakan rangkaian peristiwa-peristiwa dalam sebuah cerita. Istilah alur biasanya terbatas pada peristiwa-peristiwa yang terhubung secara kausal saja (Stanton, 2012: 26). Peristiwa kausal tersebut akan saling berkaitan dalam jalannya cerita. Jika salah satu dihilangkan, terdapat ketimpangan cerita selanjutnya.

Pengistilahan karakter biasanya dipakai dalam dua konteks. Konteks yang pertama merujuk pada individu yang terdapat dalam sebuah cerita. Konteks yang kedua mengacu pada keseluruhan campuran kepentingan dalam cerita berupa gambaran yang dimunculkan melalui satu karakter utama. (Stanton, 2012: 33).

Alasan yang mendasari karakter untuk bertindak melakukan sesuatu yang seharusnya dinamakan motivasi. Terdapat dua jenis motivasi, yaitu motivasi spesifik dan motivasi dasar.

Motivasi spesifik seorang karakter adalah alasan atas reaksi spontan, yang mungkin juga tidak disadari, yang ditunjukkan oleh adegan atau dialog terntentu. Motivasi dasar adalah suatu aspek umum dari satu karakter atau dengan kata lain hasrat dan maksud yang memandu sang karakter dalam melewati keseluruhan cerita. Arah yang dituju oleh motivasi dasar adalah arah tempat seluruh motivasi spesifik bermuara (Stanton, 2012: 33).

Alur dan karakter merupakan dua dari beberapa unsur pembangun cerita. 
Kedua unsur tersebut tidak dapat dipisahkan sebab keduanya merupakan unsur yang paling penting dari bangunan cerita. Alur menjadi sarana bagi karakter dalam bertindak. Sebaliknya, karakter menjadi tumpuan alur supaya dapat tetap berjalan dengan baik.

Terdapat beberapa karya tulis yang relevan dengan penelitian ini, yaitu Wahyuni (2017) yang membahas mengenai empat poin penelitian terhadap novel itu. Pertama, penokohan dalam menggambarkan sosok tokoh dan watak tokohnya. Tokoh-tokoh dibedakan menjadi dua: tokoh utama dan tokoh tambahan. Kedua, struktur alur mengikuti alur maju yaitu peristiwa diceritakan dari awal-tengah-puncak. Ketiga, latar dibedakan menjadi tiga yaitu tempat, waktu, dan sosial. Keempat, tema dari novel tersebut adalah perjuangan hidup seorang gadis remaja melawan sebuah penyakit. Penelaahan terhadap struktur novel merupakan persamaan dengan penelitian yang penulis susun. Namun, perbedaan terletak pada objek kajian berupa novel berjudul Dekat dan Nyaring (2019) karya Sabda Armandio.

Tuslianingsih (2010) melibatkan karya sastra berjenis prosa sebagai objek penelitiannya. Tahap penelitian berawal dari penjabaran unsur intriksik dari masing-masing novel, memberikan analisis terhadapnya, serta pada tahap akhir melakukan perbandingan pada kedua novel tersebut. Keterkaitan antara unsurunsur dalam novel merupakan persamaan penelitian tersebut dengan yang penulis lakukan, sedangkan perbedaan terletak pada objek kajiannya.

Febriana (2018) mendeskripsikan unsur intrinsik novel sebagai bahan pembelajaran di kelas. Hal ini dibuktikan dengan adanya pendekatan saintifik yang merupakan proses pembelajaran yang dikemas sedemikian rupa sehingga terdapat keaktifan para peserta didik dalam membentuk konsep tahapan mengamati, merumuskan masalah, mengajukan hipotesis, mengumpulkan data, menganalisis data, menarik simpulan, serta mengungkapkan apa yang telah ditemukan (Daryanto, 2014: 51). Kesamaan dengan penelitian ini terletak pada tahap yang menyertakan telaah unsur-unsur dalam novel.

Prihantoro (2008) membahas unsur-unsur dalam novel Towards Zero karya Agatha Christie dan juga implementasi struktur novel tersebut dalam pembelajaran sastra di SMK. Masih dengan pola penelitian yang sejenis, dimulai dari kajian tema, amanat, alur, gaya bahasa, sudut pandang, dan penokohan. Simpulan penelitian tersebut adalah novel Towards Zero mengandung nilai-nilai pendidikan yang tecermin dalam pesan moral. Selain itu, hasil penelitian tersebut dapat digunakan untuk penerapan pembelajaran sastra di tingkat SMK, khususnya bagi siswa kelas XII semester II. Terdapat relevansi struktur dengan penelitian yang penulis lakukan, namun perbedaannya terletak pada penerapan lanjutannya.

Sariningsih (2011) menggunakan teori Strukturalisme Robert Stanton, tetapi dengan objek penelitian yang berbeda berupa film dan novel Brownies. Film 
Brownies disutradarai oleh Hanung Bramantyo, sedangkan novel Brownies merupakan karya dari Fira Basuki. Penelitian ini membahas persamaan dan perbedaan struktur antara kedua objek tersebut, serta kajian mengenai fakta cerita, tema, dan sarana-sarana sastra. Hal tersebut merupakan kesamaan teori dengan penelitian yang penulis lakukan, namun perbedaan objek menjadi sebuah rangkaian pembahasan lain.

Widyawati (2016) mendeskripsikan mengenai hal-hal berkaitan dengan fakta cerita, tema, dan sarana sastra. Penggunaan sudut pandang orang ketiga dalam cerita anak yang dijadikan sebagai objek turut menjadi perhatian penelitian ini. Dengan tidak menampilkan banyak karakter, pesan yang terdapat dalam fabel tersebut dapatlah tersampaikan dengan baik dan mudah dimengerti oleh anakanak. Setiap peristiwa adalah sebab-akibat dari peristiwa yang telah terjadi sebelumnya.

\section{METODE PENELITIAN}

Menurut Abrams, pendekatan kritis yang utama terhadap karya sastra terbagi ke dalam empat jenis, yaitu pendekatan objektif, pendekatan ekspresif, pendekatan mimetik, dan pendekatan pragmatik (Teeuw, 1984: 50). Penelitian ini menitikberatkan pada karya sastra itu sendiri. Oleh karena itu, pendekatan yang akan digunakan adalah pendekatan objektif.

Metode membaca dekat diterapkan tanpa mempedulikan unsur-unsur di luar karya sastra yang bersangkutan. Pada mulanya terdapat perbedaan pendapat di antara tokoh-tokoh New Criticism. Namun, secara garis besar para tokoh tersebut setuju bahwa kritik sastra harus berpusat pada karya sastra itu sendiri tanpa membicarakan penyair sebagai pencipta atau pembaca sebagai penikmatnya. Membaca dekat merupakan pembacaan secara mikroskopi dari karya sebagai ciptaan bahasa (Teeuw, 1984:133-134).

Terdapat dua tulisan dari Wimsatt dan Beardsley yang berisi tanggapan bantahan mengenai perdebatan yang semula terjadi di lingkup para tokoh New Criticism. Tulisan pertama membantah kesalahpahaman seakan-akan pengkritik sastra berurusan dengan niat pembacanya. Selanjutnya, tulisan tersebut menegaskan bahwa hal yang tersedia bagi pengkritik hanyalah arti, makna karya tersebut, dan hanya itulah yang dapat dipahami dan dikupasnya tanpa mengikutsertakan maksud pengarang. Tulisan kedua menolak emosi, afeksi, dan sikap keterharuan pembaca sebagai jalan untuk memahami karya dengan lebih tepat (Teeuw, 1984: 134).

Adanya tulisan berisi tanggapan tersebut menekankan bahwa penelitian dengan menggunakan pendekatan objektif sudah seharusnya dilakukan dengan hanya menelaah bentuk karya sastranya. Jarak yang terbentuk di antara karya sastra dan pembaca tidak dapat dijembatani oleh peneliti sebagai salah satu dari 
pengritik sastra. Semua hal yang dibutuhkan berasal dari dalam karya sastra tersebut.

\section{ANALISIS DAN PEMBAHASAN}

Alur

Secara umum, alur merupakan rangkaian peristiwa-peristiwa dalam sebuah cerita. Istilah alur biasanya terbatas pada peristiwa-peristiwa yang terhubung secara kausal saja (Stanton, 2012: 26). Peristiwa kausal yang dimaksud adalah rangkaian cerita yang membuat atau menjadi dampak dari peristiwa yang lainnya sehingga tidak dapat diabaikan begitu saja dari potongan rangkaian peristiwa yang lainnya. Semua terlihat sama seperti unsur-unsur yang saling membangun suatu kesatuan yang utuh. Alur dalam novel Dekat dan Nyaring (2019) adalah alur campuran karena terdapat penceritaan kembali sebuah kisah pada masa lampau dan kemudian di akhir cerita terdapat sebuah jalan penyelesaian. Berikut merupakan analisis alur novel Dekat dan Nyaring (2019) yang disertai kutipan kejadian yang dialami oleh karakter-karakter dalam novel tersebut.

Cerita awal dari novel Dekat dan Nyaring (2019) mengisahkan tentang sebuah peristiwa yang juga menjelaskan kehidupan seorang karakter. Cerita dimulai dengan kalimat pembuka yang menyiratkan judul novel tersebut dan menjelaskan seluk-beluk kehidupan karakter yang memiliki semangat tinggi dalam menjalankan usahanya untuk menyambung hidup. Karakter tersebut bernama Edi. Ia tinggal di sebuah rumah yang sekaligus dijadikan sebagai warung untuk berjualan apa saja yang dapat menghasilkan uang.

SEBUAH LEDAKAN. Dekat dan nyaring. Ledakan itu berasal dari balik tembok yang membatasi warung Edi dengan kompleks Permata Permai Residence. Tak lama kemudian terdengar suara bocah tertawa, mengatai satu sama lain, disusul ledakan kedua, lalu suara tawa lagi. Edi mengangkat jerat sambil mengutuk bocah-bocah yang bermain petasan. Ia melirik kardus penuh petasan di meja warungnya dan berbicara sendiri soal kebiasaan buruk bermain petasan, setelah itu mendebat dirinya sendiri tentang keuntungan yang bisa ia dapat dengan menjual petasan (Armandio, 2019: 7).

Kehidupan ia jalani di seberang sungai yang memisahkan tempat tinggalnya dari sebuah kampung bernama Gang Patos. Kegigihannya berjuang dalam pekerjaannya membuka warung dibuktikan dengan sebuah wawancara dengan seorang manajer swalayan. Itu pun diawali dengan sebuah penolakan dari seorang satpam yang menjaga swalayan tersebut, tetapi akhirnya Edi diperbolehkan untuk menemui sang manajer.

Manager toko datang bersama satpam. Mereka mengusir Edi, tapi Edi berkeras ingin mewawancarai sang manager. Ia bilang ia ingin membuat 
toko 24 jam juga, ia penasaran dengan sistem yang diterapkan swalayan itu. Sang manager, antara bersimpati dan merasa tersanjung, meminta Edi ikut ke ruangannya. Di dalam ruangan itu sang manager menyerahkan sebuah buku otobiografi bersampul orang tersenyum dengan ibu jari teracung. Ia menunjuk-nunjuk orang di sampul itu dan berkata bahwa pendiri swalayan itu dan perumahan di seberang itu punya tiga hal yang menjadi modal awal: keyakinan, pikiran positif, dan sedikit uang. Edi membaca buku itu dalam sekali duduk. Ia yakin ia punya keyakinan, dan merasa pikirannya cukup positif. Ia merogoh saku dan mendapati dua lembar lima puluh ribuan; ia punya uang sisa (Armandio, 2019: 14-15).

Edi merupakan orang yang bersemangat, tetapi ia terkadang tidak dapat memikirkan hal yang lebih mendalam selain keberaniannya untuk memulai. Dalam bergaul pun Edi tidak mendapat masalah serius dari para tetangga penghuni Gang Patos. Kehidupannya cenderung santai dan mengalir seperti apa adanya. Tidak ada cita-cita yang muluk. Semua ia jalani dengan pikiran positif, seperti saat ia bertemu dengan Kina, istri dari Idris, temannya.

Ia menceritakan kejadian itu pada Kina, istri Idris yang gemar bertanya, dan setelah mendengar cerita itu Kina tertawa, menepuk pundak Edi, dan berkata bahwa warung Edi seribu kali lebih baik daripada swalayan itu. Saat itu, Edi mempertanyakan kapasitas otak Kina, bagaimanapun swalayan itu terlihat seribu kali lebih asyik ketimbang warung bobroknya dan Kina menjawab: Karena kau menguasai alat produksimu sendiri, sementara pegawai-pegawai yang bekerja di swalayan itu tidak memiliki apa-apa. Gaji yang mereka terima setiap bulan dan waktu yang mereka berikan untuk bekerja tak sebanding dengan apa yang didapat pemilik swalayan itu. Edi menyedot minuman dinginnya, tetap tak mengerti ucapan Kina. Bagi Edi, swalayan itu adalah keajaiban. Ia memberi kebahagiaan bagi anak-anak, dan memberi banyak peluang bagi Edi bereksperimen (Armandio, 2019: 15-16).

Meskipun hidup sederhana dan cenderung tidak berkecukupan, Edi tetap bersikap dermawan. Ia belum berkeluarga dan untuk menghasilkan uang pun ia harus memutar otak sedemikian hingga. Namun, terlepas dari permasalahan materi, ia tetap baik. Salah satunya kepada Wak Eli dan anaknya yang bernama Aziz. Wak Eli yang masa mudanya pernah terlibat dalam sebuah film berjudul Balada Cewek Jagoan, kini di masa tuanya harus mengurus anak semata wayangnya bernama Aziz yang memiliki keterbelakangan mental. Kecerdasan mentalnya tertinggal sepuluh tahun dibandingkan usia yang sebenarnya.

Seorang ibu duduk di depan rumah itu. Ia mengomeli kucingnya yang terlalu rakus. Kucingnya mengerang, melompat dari pangkuannya, lalu 
mendekati kaki Edi, mencari perlindungan. "Wak Eli sudah makan?” tanya Edi, “Aku punya roti di warung." Wak Eli mengangguk, "Tapi, mungkin Aziz mau makan." "Suruh Aziz ambil sendiri di warung. Khusus buat Wak Eli dan Aziz, semua barang di warungku adalah milik kalian. Tak perlu sungkan." (Armandio, 2019: 17).

Gang Patos adalah sebuah perkampungan ilegal di tepi kota. Kehidupan bertetangga dan saling sapa tidak dapat terhindarkan dalam keseharian hidup di sana. Seperti Edi yang kembali bertemu dengan Idris, kawannya. Berikut adalah kutipan yang menegaskan bahwa karakter Edi tidak mudah putus asa dan terus menyemangati dirinya sendiri walaupun orang lain tidak satu pemikiran dengannya.

"Sudah kubilang," ujar Idris, tertawa sendiri. "Gang ini tak bakal menjepitmu saat kau lewat. Santai sajalah, Ed." Edi terengah-engah, berusaha mengatur napas. "Ed, Ed. Kau mungkin bisa membuka warungmu enam belas jam saja," ujar Idris, menunjuk triplek yang dikempit Edi. "Seberapa sering, sih, kau mendapat pelanggan malammalam?" "Selalu ada jalan lain," jawab Edi, kalimat pamungkas yang selalu muncul tiap kali ada orang yang memaksanya berhenti (Armandio, 2019: 18-19).

Tahap awal berakhir di halaman 21. Selanjutnya, akan dirincikan mengenai tahap tengah yang saat muncul karakter bernama Nisbi dan anaknya yang bernama Anak Baik. Anak Baik merupakan karakter sentral dalam novel Dekat dan Nyaring (2019) karya Sabda Armandio. Novel ini tidak dibatasi oleh bab-bab cerita, tetapi terdapat tulisan yang diketik dengan menggunakan huruf kapital di awal paragrafnya. Tulisan tersebut menandakan seputar cerita dalam bagian tersebut.

Tahap tengah dalam novel Dekat dan Nyaring (2019) diawali dengan kehidupan seorang karakter bernama Nisbi. Ia adalah janda dari seorang polisi. Nisbi memiliki seorang anak bernama Anak Baik. Anak Baik dan Aziz, anak dari Wak Eli, berteman baik. Mereka sering menghabiskan waktu bersama untuk menonton kartun dan bermain. Karakter bernama Aziz merupakan anak dari Wak Eli yang sudah dimunculkan di tahap awal alur cerita. Pada awal cerita di tahap tengah, terdapat penulisan dengan menggunakan huruf kapital sebagai tanda bergantinya bab penceritaan dalam novel Dekat dan Nyaring (2019).

SEBUAH LEDAKAN. Dekat dan nyaring. Nisbi mengintip dari pintu kamar, jam dinding di ruang tengah menunjukkan pukul sepuluh lewat lima belas. Di bawah jam dinding, televisi menayangkan film kartun lawas Tom and Jerry: aksi kejar-kejaran tikus dan kucing, seekor anjing yang memakai seragam dan helm khas tentara menembak-nembaki si kucing. $\mathrm{Si}$ kucing jemawa, mengira tembakan meleset. Namun, saat ia minum, air mengocor dari tubuhnya yang bocor. Tikus tertawa. Anak perempuannya 
itu terpingkal-pingkal menyaksikan adegan itu. Aziz, anak tetangganya, menemani anaknya menonton sambil meringkuk di lantai. "Hei, anak baik tidak boleh menggigiti kuku," seru Nisbi kepada anaknya. "Tidak boleh," ulang Aziz. "Iya, Bu," jawab Anak Baik, menjauhkan kuku jari dari gigi. “Iya, Aziz." (Armandio, 2019: 22).

Nisbi mengajarkan hal-hal baik kepada anaknya, termasuk menyayangi makhluk hidup seperti tanaman dan binatang. Kedua spesies makhluk hidup itu dinamai Keluarga Maskoki dan Keluarga Ana Mayuri. Keluarga Maskoki merupakan sebutan untuk ikan maskoki yang hidup di akuarium, sedangkan Keluarga Ana Mayuri berupa bibit-bibit tanaman yang disemai. Seperti yang terlihat pada penggalan kutipan di bawah ini.

Nisbi mengeluarkan plastik kecil berisi biji-bijian, memperkenalkan bijibijian itu sebagai Keluarga Ana Mayuri. Anak Baik meletakkan biji di atas kapas basah. Nisbi melingkari kalender dengan spidol merah sambil memuji Anak Baik: ia telah membuat lingkungan yang baik untuk tumbuh kembang Keluarga Ana Mayuri dan, sebagai anak yang baik, ia harus menyayangi makhluk hidup lain seperti ia menyayangi diri sendiri. Anak Baik mengangguk dan bergembira, ia menamai benih itu satu per satu. Begitulah ia mendapatkan pelajaran pertamanya (Armandio, 2019: 23).

Setelah kisah itu, muncullah karakter bernama Sam. Sam tidak disukai oleh Anak Baik sebab ia beranggapan bahwa Sam sama seperti Tom yang suka mengganggu ketenangan Jerry. Menurutnya, hal itu tidak baik untuk dilakukan. Ketidaksukaan Anak Baik terhadapnya bukanlah tanpa alasan. Sesaat sebelum Sam memasuki rumah Nisbi sebagai seorang tamu, Nisbi telah terlebih dahulu menutupi Keluarga Ana Mayuri dengan pakaian-pakaian kotor. Pakaian-pakaian kotor itu menimpa Keluarga Ana Mayuri hingga tidak mati dan Anak Baik sedikit melakukan protes terhadap pernyataan Nisbi sebelumnya bahwa ia harus menyayangi makhluk hidup lain seperti menyayangi dirinya sendiri.

Nisbi lekas-lekas meninggalkan kamarnya menuju tempat akuarium, ia menutup seluruh akuarium dengan tumpukan pakaian kotor, sebelum menjawab panggilan tamu. Pakaian-pakaian itu menimpa pot-pot tanaman. Batang-batangnya patah dan beberapa daun yang masih sangat muda gugur. Anak Baik hampir menangis saat menemukan bagian yang paling ia sayangi, kuncup yang wanginya mengingatkan Anak Baik pada bau badannya sendiri, jatuh dan terinjak oleh kakinya. Setelah merusak Keluarga Ana Mayuri, tanpa menjelaskan apa-apa, Nisbi membukakan pintu untuk tamu (Armandio, 2019: 23-24). 
Terdapat hal tersirat yang akan diketahui setelah membaca novel ini sampai di bagian tengah menjelang akhir cerita. Termasuk pengalihan cerita yang dimulai dari bagian ini. Novel Dekat dan Nyaring (2019) seperti memiliki dua tema yang beriringan dalam cerita. Namun, hal ini hanyalah sebagai pengantar bagi topik selanjutnya yang dengan sengaja dikembangkan oleh penulis.

Pada potongan cerita selanjutnya, Anak Baik selalu menanyakan tentang hal-hal yang ingin ia ketahui (sebagai seorang anak yang serba ingin tahu) kepada orang-orang dewasa yang ditemuinya. Banyaknya versi cerita yang muncul terkadang membuatnya bingung. Di balik kegigihan Anak Baik dalam bertanya, sebenarnya ia hanya ingin mengetahui sebuah cara yang dapat membuat ayahnya kembali ke sisinya dan membuat keluarganya menjadi utuh sehingga ibunya bahagia. Ia tidak mengetahui bahwa sebenarnya ayahnya sudah meninggal dunia. Hal inilah yang menjadi rahasia sekaligus membuat cerita menjadi kompleks.

"Aku bisa menyelamatkan orang banyak," kata Sam, "seperti suamimu." "Siapa itu Pak Koksi?" tanya Anak Baik, "Tadi Pak Sam dan Ibu membicarakan Pak Koksi, sepertinya dia orang hebat." “Oh," jawab Sam, "Pak Koksi bisa melakukan apa saja." "Kalau begitu dia bisa menghidupkan Ayah, dong?" Sam dan Nisbi saling berpandangan. "Pak Sam, bukannya tadi sedang cari kucing?" tanya Nisbi, dan seolah mengerti Sam, sekali lagi, membenarkan posisi ikat pinggangnya (Armandio, 2019: 29-30).

Di situlah semua perkara tentang Pak Koksi dimulai. Sebuah dongeng yang tersebar di Gang Patos dan menjadi sebuah pemikiran serius bagi Anak Baik yang nalarnya dapat dibilang masih seumur jagung. Mula-mula Anak Baik menanyakan apa yang ada di dalam benaknya kepada Aziz.

Rengekan Anak Baik menyadarkan Nisbi. Anak Baik memaksa Nisbi menjelaskan siapa itu Pak Koksi, "Semua orang membicarakan Pak Koksi," ujar Anak Baik, "kemarin Bang Edi dan Bibi Kina membicarakan Pak Koksi, barusan Pak Sam dan Ibu." "Aziz," panggil Anak Baik, "Kau kenal Pak Koksi?" Aziz menggeleng, "Tapi kartunnya sudah habis." "Besok kau boleh datang lagi, kita nonton kartun bareng lagi. Sekarang aku mau tahu soal Pak Koksi dan Ibu akan menjelaskan. Iya kan, Bu?" (Armandio, 2019: 30).

Melihat tingkah anaknya yang sangat ingin mengetahui kisah tersebut, Nisbi pun akhirnya mulai menceritakannya dengan sebuah syarat bahwa Anak Baik harus menghentikan rengekannya dan Aziz tidak diperbolehkan menyela ketika cerita sedang dibacakan.

Nisbi memulai ceritanya dengan sebuah kalimat pembuka yang tak bisa ditolak Anak Baik: "Pada zaman dahulu satu keluarga pengelana - ibu, 
ayah, dan seorang anak perempuan. Mereka berkelana dengan naik sampan, menyusuri sungai yang deras hingga si ayah melihat daratan yang ditumbuhi dengan bunga-bunga. Warna-warni bunga itu menarik perhatiannya. Ia memutuskan menepi ..." (Armandio, 2019: 31).

Kisah yang diceritakan Nisbi bermula dari keputusan keluarga pengelana tersebut untuk menembus sekumpulan semak-semak dan akhirnya di tepi sungai menemukan kumpulan belulang berumur sekitar ratusan tahun dari seekor naga yang kurus. Singkat cerita, si ayah dalam kisah tersebut harus pergi untuk memberi tahu kelompok nomadennya bahwa telah ditemukan tempat untuk tinggal dan menetap. Ia berpesan kepada sang anak untuk menjaga ibunya.

Beberapa hari kemudian, kelompok nomaden tiba. Sang ayah tetap belum terlihat. Kemudian, sang ibu memutuskan untuk memimpin kelompoknya. Di akhir hayatnya, ia meninggal dalam keadaan berjongkok sambil memegang tongkat di tepi sungai dengan harapan bahwa ketika sang ayah pulang ialah yang pertama kali menyambutya. Si anak perempuan yang mendapat julukan Samwau (yang berarti orang yang terampil membuat sampan) dan anggota kelompok lain pun bersedih. Di masa-masa itulah datang gerombolan berjubah merah dan hitam seperti pada kutipan di bawah ini.

Di masa perkabungan, datanglah gerombolan yang berjubah merah dan hitam. Gerombolan itu dipimpin oleh seorang lelaki agak tua dan senyumnya menyiratkan kebijaksanaan. Ia memperkenalkan kaumnya sebagai Orang Koksi, ia sendiri menyebut dirinya Pak Koksi (Armandio, 2012: 36).

Pak Koksi memulai sebuah pembicaraan dengan Samwau dan mengatakan bahwa ia dan kaumnya yang pandai dalam beternak akan menempati wilayah di seberang sungai. Ia pun memperbolehkan jika Orang Patos ingin ikut serta dengannya untuk tinggal di sana. Namun, Samwau menolak.

Samwau menolak tawaran itu dengan halus. Ia menjelaskan bahwa Orang Patos sudah serba cukup. Meski begitu ia tak keberatan jika Orang Koksi hendak menjalin hubungan dagang. Orang Patos punya banyak tanaman yang bisa ditukar dengan hasil ternak. Pak Koksi setuju. Keduanya sepakat bekerja sama membangun jembatan (Armandio, 2012: 37).

Ketika Nisbi tengah larut dalam cerita tersebut, tiba-tiba Edi memanggil. Bagian inilah yang menandai kemunculan karakter utama bernama Edi. Ia selalu bersinggungan dengan seluruh karakter dalam novel Dekat dan Nyaring (2019). Kehadirannya di bagian ini menjadi tanda sebuah kisah lanjutan di luar perkara dongeng yang diceritakan oleh Nisbi kepada Anak Baik. 
Suara seseorang memanggil nama Nisbi. Ia kenal pemilik suara itu. Edi si penjaga warung. Nisbi menghentikan cerita dan menutup buku. Ia melirik jam dinding, sudah hampir pukul sebelas. Ia meminta Anak Baik bersabar, "Nanti Ibu lanjutkan lagi ceritanya. Sekarang Ibu harus ketemu Bang Edi, ia pasti membetulkan akuariumnya." “Tapi, apa Bang Edi bisa menghidupkan Keluarga Ana Mayuri lagi?" "Bang Edi bahkan bisa menghidupkan orang mati, sayang. Anak Baik tunggu di rumah dan harus apa?" "Harus bersikap baik." “Betul," jawab Nisbi, mencubit dan mencium pipi Anak Baik, lalu bergegas membuka pintu (Armandio, 2012: 37).

Meskipun Nisbi telah menceritakan secara panjang lebar mengenai cerita Pak Koksi, Anak Baik tidak menaruh rasa percaya begitu saja. Sebagai anak perempuan yang masih belum berani tidur sendiri di dalam kamarnya, hal ini menjadi amat seirus. Ia ingin memastikan kebenaran yang paling benar.

Keduanya lalu menghilang dari pandangan Anak Baik. Anak Baik berdiskusi dengan bantal kursinya, "Kau percaya cerita Ibu?" Bantal kursi, seperti biasa, anteng-anteng saja. “Kalau kau, Ziz?" “Mungkin ibuku lebih tahu," jawab Aziz. "Hm, aku pikir juga begitu. Kita tanya kepada ibumu, yuk!" (Armandio, 2012: 38).

Ketika Anak Baik dan Aziz bergegas menuju kediaman Wak Eli, Kina memanggil Aziz untuk kembali belajar. Anak Baik yang sudah tidak sabar lagi mendengar versi cerita yang lain langsung bergegas menuju rumah Wak Eli sendirian. Ini sekaligus menjadi akhir sebelum cerita berganti ke babak yang baru. Seperti yang penulis katakan sebelumnya, babak baru akan ditandai dengan adanya penulisan menggunakan huruf kapital di awal kalimat.

WAK ELI selalu menekankan kejujuran kepada Aziz, anaknya yang berusia dua puluh dua tahun tetapi memiliki usia mental sepuluh tahun lebih muda, dan Anak Baik. Wak Eli selalu berbau minyak kayu putih, bau yang membuat Aziz dan Anak Baik merasa tenang dan mengantuk. Wak Eli bisa membicarakan soal betapa pentingnya menjadi orang jujur sampai Aziz dan Anak Baik tidur. Wak Eli pernah menceburkan diri ke sungai hanya agar Aziz dan Anak Baik melupakan gosip tentang buaya buntung yang suka memakan anak-anak. Wak Eli tak pernah memarahi Aziz dan Anak Baik. Tak ada alasan bagi Anak Baik untuk tak percaya pada Wak Eli (Armandio, 2012: 39).

Anak Baik menjelaskan tentang apa yang ia tangkap dari cerita yang dituturkan oleh ibunya. Hal itu sempat membuat Wak Eli tertawa dan mengatakan apa yang sejujurnya. Seperti apa yang sudah selalu dikatakannya 
kepada Aziz dan Anak Baik bahwa kejujuran itu sangatlah penting. Kutipan berikut ini akan merincikan kejadian dalam ceritanya.

"Begitulah cerita buku ini, Wak," ujar Anak Baik. "Naga itu, kan, nggak ada. Masa ibuku masih percaya hal seperti itu, sih?" Wak Eli tertawa kecil melihat judul buku yang diawa Anak Baik, lalu berkata, “Kecuali naga, semua cerita ibumu mungkin memang benar terjadi." Ia memuji kecerdasan Anak Baik, dan inisiatifnya mencari kebenaran lain. Setelah itu ia bangkit dari kursinya, masuk rumah, dan kembali dengan membawa buku yang lebih tebal. Tafsir Al-Misbah volume 12, satu-satunya volume yang ia miliki dan buku paling tebal yang ada di rumahnya. Ia menunjukkan buku itu kepada Anak Baik dan berkata versi di buku ini mungkin yang paling mendekati kebenaran (Armandio, 2012: 39-40).

Anak Baik mendatangi Wak Eli dengan tujuan untuk mendapatkan cerita yang lebih dapat dipercaya kebenarannya. Pada awal pembacaan kisah, Nisbi mengambil buku berjudul Cara Jitu Menembus Ujian Psikotes dan Tes Akademik SECAPA POLRI (Armandio, 2012: 31). Namun, ternyata Wak Eli juga melakukan cara yang sama, meskipun ia selalu menekankan kejujuran kepada dua anak tersebut.

Anak Baik membanding-bandingkan dua buku tebal di tangannya, "Punya Wak Eli kelihatan lebih tua dan kusam, pasti lebih benar." Wak Eli tersenyum. Ia menyuruh Anak Baik duduk di pangkuannya. Wak Eli membuka halaman pertama. "Seperti yang diceritakan ibumu, memang benar Orang Patos membangun desa yang amat bagus - tentu tanpa tulang naga, dan di seberangnya Orang Koksi mulai membangun desa yang sama sekali berbeda." Orang Koksi memulainya dengan membabat seluruh pohon karet. Setelah memiliki tanah yang cukup lapang, mereka mulai membangun rumah-rumah dua lantai. Selain itu, Orang Koksi juga membuka lahan untuk hewan ternak mereka dan memagarinya agar hewan-hewan itu tidak kabur. Jembatan yang dibangun bersama-sama rampung menjelang musim mangga, barang pertama yang diperdagangkan adalah mangga dan daging sapi, selain itu Orang Koksi juga menukar ilmu obat-obatan dengan ilmu bercocok tanam yang dikuasai Orang Patos. Kedua tetangga itu hidup berdampingan selama beberapa musim (Armandio, 2012: 40-41).

Kedua kaum yang semula rukun tanpa ada keinginan lebih dari salah satu pihak, kini mulai goyah. Hal itu ditandai dengan datangnya Pak Koksi menemui Samwau dengan maksud seperti semula, yaitu ingin menyatukan dua desa supaya memiliki tanah yang lebih luas dan juga sumber daya alam yang lebih 
lengkap. Namun, lagi-lagi Samwau menolaknya secara halus. Permasalahan muncul saat tibanya musim hujan.

Musim hujan tiba. Suatu sore, seorang tak dikenal masuk wilayah Orang Patos, orang itu bersin-bersin sampai pingsan. Orang Patos menolong orang itu, sebagai gantinya beberapa hari kemudian sebagian besar Orang Patos ikut bersin-bersin. Pak Koksi menjelaskam, menurut tabib-tabib Orang Koksi, bersin-bersin itu muncul karena mereka kedinginan. Pak Koksi juga membuka peluang emas bagi Orang Patos. Ia akan memberi satu rumah dan mantel bagi Orang Patos yang bersedia tinggal wilayah yang sudah disediakan Orang Koksi, serta tabib-tabib yang siap mengobati. Pada puncak musim hujan, beberapa Orang Patos yang bersinbersin mengambil kesempatan itu (Armandio, 2012:41-42).

Anak Baik menarik kesimpulan yang benar dari cerita yang disampaikan oleh Wak Eli bahwa lama kelamaan kampung tempat tinggal Orang Patos semakin sepi. Wak Eli pun membenarkan dengan menyambung ceritanya yang belum selesai. Pada lanjutan ceritanya, Samwau menemui Pak Koksi dan membicarakan penyebab hilangnya orang-orang tersebut dan akhirnya diketahuilah bahwa Siluman Buaya Buntung yang menjadi penyebabnya.

Setelah peristiwa itu, Samwau memutuskan untuk membongkar rumahrumah dan menjauhkannya dari tepi sungai. Orang Koksi membantu proses itu, sambil berusaha meyakinkan Orang Patos untuk pindah ke tempat yang lebih layak. "Hasilnya, semakin banyak Orang Patos yang pindah." “Pengaruh Pak Koksi sebesar itu ya, Wak?" "Konon dia juga bisa menemukan orang hilang, dan itulah yang dijanjikan kepada Samwau setelah tahu tujuan dibalik eksperimen-eksperimen Samwau membuat sampan." "Itu juga tujuanku mau memanggil Pak Koksi, Wak." "Memang kau mau apa?" "Memanggil Ayah," jawan Anak Baik, "Kata Pak Sam cuma Ayah yang bisa menyelesaikan masalah (Armandio, 2012: 42-43).

Sebenarnya, Anak Baik juga tidak mengerti apa maksud dari ucapan Pak Sam mengenai masalah apa yang dapat diselesaikan oleh ayahnya. Anak baik berkesimpulan bahwa jika masalah tersebut selesai, maka ibunya akan menjadi senang dan Pak Sam, orang yang tidak ia sukai, berhenti mendatanginya. Wak Eli pun kelelahan menyampaikan cerita dan memberi tahu sebuah rahasia. Hal tersebut ia lakukan supaya Anak Baik berhenti bertanya.

Wak Eli memberi tahu Anak Baik sebuah rahasia: kalau Anak Baik bisa mengumpulkan tujuh laba-laba, Pak Koksi akan datang sendiri menemuimu. Anak Baik langsung bertanya kenapa harus tujuh dan Wak Eli menjawab santai: "Tujuh itu angka kesukaan Nabi." Anak Baik menggeleng lemah, ia menjelaskan bahwa saat ini laba-laba susah dicari 
dan kalaupun ada pasti sulit ditangkap, "Terlalu kecil," kata Anak Baik, "dan terlalu gesit. Mereka bisa melompat dari gedung ke gedung." "Tapi, kan, di sini tidak ada gedung. Di rumah-rumah kosong itu pasti banyak sekali laba-laba. Anak Baik cuma perlu apa?" "Bersabar!" “Betul sekali. Selain itu, bekerja keras." (Armandio, 2012: 44).

Setelah itu, Wak Eli menyuruh Anak Baik untuk kembali pulang ke rumahnya. Ketika dalam perjalanan pulang, Anak Baik berhenti di depan sebuah rumah kosong dua lantai. Ia mengintip melalui celah dari antara papa lalu di sana ia melihat Nisbi sedang berbincang dengan Edi. Tak berapa lama kemudian, Edi pun beranjak mengunjungi rumah Nisbi dan di sana ia mendapati Anak Baik telah berada di dalam rumah. Pada bagian ini, terdapat pejelasan mengenai tanaman apa yang sebenarnya ditanam oleh Nisbi. Selama ini Nisbi telah menghabiskan dananya untuk proyek akuaponiknya bersama Edi.

"Anak-anak di Permata Permai Residence sudah nggak mau gele," uajr Nisbi. "Jadi kau sudah kehilangan semangat?" “Aku sudah menggunakan tabungan untuk menyekolahkan anakku buat proyek akuaponikmu. Aku pikir bisa menunggu panen, tetapi malah jadi begini. Dua puluh pot, yang hidup cuma empat." (Armandio, 2012: 47).

Jadi, demi melanjutkan hidupnya, Edi dan Nisbi bersepakat untuk menjual ganja. Hal ini telah ditandai dengan sifat Edi yang tidak putus asa dan mencari segala cara untuk menyambung hidupnya. Setelah mengetahui akuaponiknya tidak berjalan dengan lancar, Edi memutuskan untuk berpindah ke lahan lain. Setelah adanya keputusan tersebut, cerita kembali berkutat dengan kisah Pak Koksi. Kali ini Edi dan Nisbi saling melengkapi menyampaikan kisah tersebut. Terdapat penyampaian pesan yang sebenarnya tidak dihiraukan. Hanya diucapkan saja untuk sekadar memberi nasihat seperti pada kutipan berikut.

Edi menggendong Anak Baik dan berkata bahwa ia akan melanjutkan cerita. Anak Baik memprotes, menurutnya semua cerita harus bersumber dari buku karena kata ibunya buku adalah jendela dunia. Edi berkilah, "Cerita Orang Patos dan Orang Koksi itu diketahui seluruh orang dewasa di sini, mereka sudah hafal di luar kepala." "Kalau tidak dari buku aku tidak akan percaya." "Anak baik, ada banyak hal di dunia ini yang tidak ada di dalam buku." "Itu artinya hal-hal itu belum bisa diperjawabkan." "Pertanggungjawabkan?" “Pokoknya begitu." (Armandio, 2012: 52).

Kegigihan Anak Baik untuk memperoleh cerita yang benar berlanjut pada kisah selanjutnya yang dituturkan oleh Edi. Edi menyampaikan cerita dengan bumbu-bumbunya sendiri sehingga topik beralih lagi. Kali ini Edi menambahkan 
karakter bernama Beni Satria dengan segala keanehannya dalam dongeng tersebut. Semua berakhir ketika Anak Baik bertanya kepada Edi.

"Eh, Bang Edi, menurutmu mungkin nggak Pak Koksi menculik ayah Samwau?" Edi dan Nisbi saling memandang. "Ya, mungkin saja," jawab Edi. Nisbi mengalihkan pembicaraan dengan menyerahkan kabel dan berkata bahwa sudah saatnya Edi menghidupkan keluarga Ana Mayuri. Anak Baik terlihat begitu bersemangat. Edi menanyakan kesungguhan Anak Baik menghidupkan Keluarga Ana Mayuri. Anak Baik menjawab dengan terlalu antusias. Edi meminta tolong Anak Baik berjaga di rumah seperti seorang kapten kapal menjaga rumahnya dari perompak; terutama dari Pak Sam (Armandio, 2012: 59-60).

Hal tersebut sangat tersirat. Menanam ganja sebagai sebuah bentuk pelanggaran. Oleh karena itu, kesibukan mereka tidak boleh diketahui oleh siapa pun agar tetap dapat berjalan lancar tanpa hambatan. Anak Baik yang sedang sendirian sebab ditinggalkan oleh Nisbi dan Edi mengurus suatu keperluan memutuskan untuk pergi ke rumah kosong mencari laba-laba. Di sana ia bertemu dengan Kina dan merengek untuk diberitahu cara menemui Pak Koksi. Sebelumnya, Kina telah menawarkan diri untuk membantu Anak Baik. Awalnya, Kina menjelaskan perbedaan kepik dan koksi.

Kina mondar-mandir di depan keduanya. "Pertama," kata Kina, "kamu harus tahu dulu beda kepik dari koksi. Ada yang tahu?" Aziz menggeleng keras. Melihat Aziz menggeleng, Anak Baik ikut menggeleng. "Kepik berwarna oranye dengan corak hitam di punggung, sementara koksi adalah kumbang dengan punggung keras berwarna merah dengan bulatan-bulatan hitam," terang Kina, "ini penting sebab orang asing sering menyamakan keduanya" (Armandio, 2012: 63).

Cerita kembali beralih pada usaha Nisbi dan Edi dalam mencari rezeki. Ketidaksanggupan menerapkan akuaponik pada Keluarga Ana Mayuri menjadi alasan di balik semua ini. Edi mengajak Nisbi untuk melakukan transaksi dengan cara lain, tidak semestinya. Edi memiliki ide dan menyampaikannya kepada Nisbi dengan segala pertimbangannya mengenai untung dan rugi dari ide yang menurutnya cemerlang itu.

"Sekarang kita petik daun-daun ini sebanyak-banyaknya." Nisbi berdecak, "Ini penipuan, Ed." "Sedikit saja, Tuhan akan maklum. Ya, kira-kira sampai kau punya cukup modal untuk menjual ganja dengan jujur." “Tak ada urusan dengan Tuhan. Pelangganku jauh lebih penting. Aku membayangkan perasaan mereka jika tahu, Ed. Sepintar apa pun dirimu, mereka lebih pintar lagi buat urusan mabuk. Mereka sudah mengisap ganja sejak SD." "Menurut Kina, sih, bau ganja dan daun kembang bokor 
tak ada bedanya. Aku sendiri nggak yakin, tapi kita akan segera tahu." "Sepertinya, Kina itu agak bermasalah." "Bermasalah bagaimana? Menurutku, Kina adalah perempuan paling pintar yang kukenal. Ia sering berbagi informasi yang menarik dan berguna, dan ia sering memberi anakmu buku-buku cerita yang bagus." "Kau jangan gampang percaya pada orang baru, Ed." (Armandio, 2012: 67).

Dari kutipan tersebut terlihat bahwa Nisbi sangat waspada terhadap lingkungan di sekitarnya. Meskipun begitu, Edi selalu membujuk Nisbi untuk melakukan hal gilanya dan saling melengkapi demi mendapatkan uang. Tahun depan, Anak Baik sudah harus mulai masuk sekolah. Jadi, mau tak mau Nisbi seperti menyetujui ide tersebut dan mereka berpindah ke sebuah rumah tetangga Nisbi yang sudah lama tidak ditinggali untuk meracik daun kembang bokor.

"Mau kautaruh di mana? Rumahku sempit." "Kan ada rumah tetangga." "Kau gila, ya? Itu dekat sekali dengan kantor polisi." "Lho, rumah tetanggamu sudah lama kosong. Daripada sia-sia, lebih baik difungsikan lagi." Nisbi menarik napas panjang. "Lagi pula akan menguntungkan kita. Polisi-polisi sialan itu nggak akan berpikir ada yang berani aneh-aneh di dekat wilayah kekuasaan mereka," ujar Edi, "kata siapa itu, tempat sembunyi terbaik adalah di sarang musuh." (Armandio, 2012: 70).

Nisbi yang kemudian mendengar suara anaknya di seberang sungai saat ia berada di warung Edi memutuskan untuk memanggil Anak Baik dan mengirimkan roti juga minuman dingin untuk mereka di sana. Anak Baik yang sedang sibuk bermain dengan Aziz didampingi Kina dan Idris mendengar suatu suara yang tak bisa ia hindari. Ia adalah Sam yang membawa layang-layang berwarna kuning. Kina dan Idris telah melarang mereka bermain, tetapi Sam mengajak dan mereka pun sangat tergoda untuk bermain layang-layang. Kina dan Idris pun kembali ke rumahnya.

"Kadang aku ingin tahu apa yang kautulis tentang aku di buku-buku itu." "Nggak ada yang personal, kok. Pengamatan sehari-hari saja. Mirip catatan tagihan utang, kau pasti bosan membacanya," jawab Kina, menyembunyikan berkas berjudul 'IDRIS-063' dengan tangannya, "ini penting buat kalian." "Begitu, ya," jawab Idris, menopang dagu dengan tangan kiri, "jadi tiga tahun kautinggal di sini cuma menulis buku tagihan utang?" "Iya, cara kerjanya mirip catatan utang. Membantu mengingatkanku pada hal-hal yang terjadi di sini." (Armandio, 2012: 76).

Hal itulah yang dilakukan Kina semenjak kepindahannya ke Gang Patos. Menulis catatan, merekam semua pembicaraan termasuk dengan suaminya dan dalam keadaan apapun. Percakapan berlanjut dengan kenangan-kenangan 
pertemuan mereka di depan sebuah miniswalayan 24 jam. Lalu saat Idris beranjak pergi, Kina memanggil dan minta diantarkan ke rumah Nisbi. Ia tidak melupakan alat perekam dan catatannya. Inilah yang menjadi akhir alur tahap tengah.

Pada tahap akhir, cerita dimulai dengan kisah Kina dan Idris. Melanjutkan kisah pada tahap tengah, tetapi akan berakhir dengan topik penutup pada novel Dekat dan Nyaring (2019) ini. Penulisan menggunakan huruf kapital pada kata-kata di awal kalimat menjadi ciri khas penulis.

SEBUAH LETUPAN. Dekat dan Nyaring. Idris menunduk dan melihat ke belakang, berusaha melihat moncong knalpot motornya. Setiap kali Idris menarik gas sebuah letupan disertai asap hitam keluar dari ujung knalpotnya. Kina mengusir asap sambil terbatuk-batuk, ia mengomel dan mengingatkan untuk tidak membeli oli motor di warung Edi. "Warung Edi bukan bengkel motor, sayang." "Setiap kali motormu bengek, kau selalu bilang 'selama ini baik-baik saja'. Kautahu ada yang nggak beres, dan kautahu masalahnya di mana." (Armandio, 2012: 81).

Kina memanggil Nisbi sesampainya ia di depan rumah Nisbi. Ia mengatakan bahwa Sam mengajak Anak Baik dan Aziz bermain layangan. Keduanya lanjut berjalan menuju swalayan. Kina selalu menanyai Nisbi tentang fakta-fakta yang masih belum ia ketahui. Alat perekam selalu menyala sepanjang perbincangan mereka saat berbelanja. Semua pembicaraan yang awalnya tentang daun kembang bokor, memusat kepada hal mengenai ayah dari Anak Baik. Suami Nisbi meninggal ketika Anak Baik masih di dalam kandungan.

Pada malam itu, suami Nisbi pulang dengan membawa sebuah karung berisi seorang perempuan simpanannya sambil meminta maaf kepada Nisbi yang tengah mengandung Anak Baik di dalam rahimnya. Nisbi menyarankan suaminya untuk menembak perempuan tersebut dengan pistol yang selalu dibawanya ke mana-mana sebagai lulusan sebuah akademi kepolisian. Namun, suaminya selalu menyatakan bahwa ia tidak bisa melakukannya sebab terlalu berisiko. Akhirnya, Nisbi pun mengambil keputusan untuk mengambil pistol dari saku suaminya.

Nisbi mengambil pistol dari pinggang suaminya, mengarahkan moncongnya ke dinding mulut. Ia mengusap perutnya yang menggelembung seperti kena tumor ganas. Suaminya dengan gesit mengambil pistol dari tangan Nisbi lalu, tanpa sempat menarik napas, menembaki karung itu. Tiga tembakan. Suaminya menatap Nisbi, mengucap sesuatu yang tak terpahami oleh Nisbi. Nisbi melihat punggung suaminya yang tegap, dan bagaimana kedua bahu suaminya naik turun dengan cepat sebelum terdengar satu tembakan lagi. Sesuatu yang kental dan anyir mendarat di wajah Nisbi. Nisbi menjatuhkan badan ke kursi, kemudian senyap (Armandio, 2012: 89). 
Nisbi kemudian menghampiri Edi, sosok yang ia percayai untuk melakukan hal apapun itu. Edilah yang mengurus mayat-mayat tersebut. Nisbi melaporkan kejadian kepada polisi bahwa sekelompok orang mendatangi rumahnya dan membawa suaminya. Hal itu didukung oleh kesaksian para tetangga yang mendengar suara seperti senjata api dan polisi lokal yang dipimpin oleh Sam saat itu menduga bahwa kasus ini ada kaitannya dengan mafia tanah.

Kapolsek yang brilian dan bertanggung jawab, kata Sam ketika menyampaikan penghormatan terakhirnya, meninggalkan dunia dengan cara terhormat. Sesuatu yang tidak membunuh Nisbi di malam lima tahun lalu merengek di telinganya sepanjang tahun, seumur hidup, sementara suaminya lenyap dan selamanya dikenang sebagai pahlawan (Armandio, 2012: 90).

Alur ini menggambarkan kebingungan yang klise dari kedua belah pihak. Penceritaan ini di luar pembicaraan Kina dan Nisbi di swalayan. Kemudian, Kina mulai mengajak Nisbi untuk kembali membuka permbicaraan mengenai hilangnya suami Nisbi. Kali ini ia menggunakan Anak Baik sebagai alasan atas pertanyaannya tersebut.

"Keduanya tertawa. Nisbi melanjutkan, "Kadang aku iri denganmu." "Jangan bilang begitu. Kau mati-matian menghidupi anakmu sendirian. Kau pasti sering mendengar rumor aneh-aneh tentangmu, tapi kau sanggup bertahan." "Tidak ada orang yang membicarakanku, Kin." "Masak, sih?" "Karena kita nggak punya tetangga, kan?" Keduanya tertawa lagi, dan berhenti ketika Kina berkata, "Pikirkan lagi tawaranku tadi." "Tawaran apa?" "Tak ada salahnya melepas rasa curigamu kepadaku, sebentar saja, dan ceritakan kepadaku apa yang sudah kaulalui." (Armandio, 2012: 91).

Selanjutnya, muncullah karakter bernama Dea Anugrah. Ia adalah penghubung antara Kina dengan dunia kepenulisannya yang selama ini ia sembunyikan dari orang-orang di Gang Patos, tempat ia tinggal selama tiga tahun terakhir ini bersama Idris. Dea menyarankan kepada Kina untuk mengutarakan kepada mereka bahwa ia merekam pembicaraannya selama ini. Namun, Kina menyanggah dengan kutipan berikut.

"Berapa kali harus kukatakan sampai kau mengerti? Aku nggak sedang menjadikan mereka bahan eksperimen, ini method writing, aku sedang menjadi mereka. Memangkas jarak dengan mengalami kehidupan kaum miskin kota. Tujuannya jelas, aku ingin menyuarakan penderitaan mereka." "Bagiku kau malah terlihat seperti bocah SD yang ingin menjadi kodok dengan membelek puluhan perut kodok," ujar Dea, tertawa. “Kenapa sih, kau merasa perlu mewakili mereka? Itu sama saja dengan kau 
meremehkan kemampuan mereka. Mereka bisa menyelesaikan masalah mereka sendiri tanpa perlu kau wakili." (Armandio, 2012: 93).

Kina dan Dea menyelesaikan perdebatan mereka. Kina terobsesi untuk menjadi penulis novel yang harus menggunakan metode kepenulisan untuk menyelesaikan karyanya. Barangkali ia dapat memenangkan suatu penghargaan bergengsi seperti penulis yang ia kagumi.

Kemudian, cerita beralih ke babak selanjutnya. Terjadi sebuah perkara yang menggemparkan Gang Patos. Aziz mengalami luka tembak di pelipisnya hingga merenggut nyawanya. Wak Eli hanya bisa gemetar dan kehabisan katakata menanggapi kejadian malang yang menimpa anaknya itu.

Wajahnya memerah. Tangannya gemetar. Sam berhenti berusaha menggendong mayat Aziz sewaktu menyadari kehadiran Eli. Sam berjalan mendekati Eli, mengaitkan lengan ke pundak Eli seperti seorang sahabat lama. Ia berdeham, melihat ke kanan dan ke kiri, kemudian menceritakan latar belakang mengapa peluru bisa mendarat di pelipis Aziz (Armandio, 2012: 97-98).

Kelalaian ini dilakukan oleh Sam, seorang polisi yang tengah bermain layangan bersama anak-anak dengan mengantongi sebuah pistol. Keadaan yang semula ceria menjadi mencekam. Semula Sam berniat mengoper benang layangan kepada Aziz, tetapi Aziz malah mengambil pistol dari kantongnya. Mengerti akan terjadi bahaya, Sam berusaha menghentikannya.

“Dia siap berlari ke arah Gang Patos, dan yah, kautahu kan, berlari-lari di gang dengan pistol di tangan," tambah Sam, "dan pikiran yang terganggu. Tentu berbahaya, mengancam keselamatan orang. Aku menubruknya, berusaha membuatnya menyerah. Aziz memberontak, dan menempelkan pistol ke perutku. Aku melihat kesempatan merebut pistol, dan kugunakan dengan baik, dan yah, sesuai pasal 47 Perkapolri 8 tahun 2009, aku harus menghentikan Aziz." (Armandio, 2012: 98-99).

Sam menyesali kejadian pada hari itu. Namun, ia tidak dapat berbuat apaapa selain memberikan keterangan bahwa sebenarnya ia tidak bersalah atas hal tersebut. Wak Eli hanya bisa diam sambil menatap mayat anaknya tanpa berkedip. Anak Baik yang sewaktu itu sedang menangkap laba-laba di balik semak-semak menatap mata Aziz yang sudah tidak bernyawa. Anak Baik mengetahui bahwa Aziz tidak dapat bangun lagi dan ia bergegas mencari Edi yang menurutnya dapat mengatasi segala kericuhan ini.

Edi bergegas mendatangi Nisbi karena Anak Baik telah menghampirinya lebih dulu dengan napas yang sangat terengah. Edi menyuruh Nisbi dan Anak Baik bersembunyi di warungnya untuk sementara waktu sampai keadaan 
membaik. Di ujung perjalanan mereka Nisbi terhenti ketika mendengar perkataan Anak Baik.

"Sekarang perangkapnya sudah dikubur," lanjut Anak Baik, "aku cuma perlu menunggu sampai api padam buat melihat hasil tangkapanku. Sayang sekali Aziz ditembak Pak Sam, tapi Bang Edi pasti bisa menghidupkannya lagi." Nisbi berhenti. "Ada apa?" tanya Nisbi, "tembakan apa?" Anak Baik menarik dagunya dari bahu Nisbi dan menunjuk seberang sungai. Nisbi menoleh ke arah yang ditunjuk anaknya. Ke seberang sungai. Ke barisan rumah yang mulai terbakar. Ke asap tebal yang menaungi rumah-rumah yang mulai terbakar. Susunan rumah di Gang Patos adalah sahabat api. Nisbi menurunkan Anak Baik pelan-pelan. Kakinya gemetar, lalu ia berjongkok memandangi seberang sungai (Armandio, 2012: 106).

Edi terlihat sangat susah payah menarik tali ember di seberang sungai. Ketika ember itu sampai, Anak Baik meraih sesuatu dari dalam ember itu dan menggenggamnya. Edi terlihat menceburkan diri ke sungai. Akhir dari cerita novel Dekat dan Nyaring (2019) berjalan di waktu dua puluh tahun kemudian. Ketika Anak Baik sudah beranjak dewasa dan saat itu ditemani oleh penulis tua. Seorang karakter yang sempat muncul, ia bernama Dea.

Anak Baik tak punya banyak waktu. Ia punya pekerjaan yang harus segera ia tuntaskan segera sebelum Dea, penulis tua bangka yang menunggu di motor, mengejek tulisannya bahkan meski sudah mendapat bahan yang sangat cukup. Sambil menggali tanah ia mengingat-ingat dongeng Orang Patos dan Orang Koksi. Orang-orang di dalam dongeng itu terasa dekat sekaligus tak terjangkau; tak bisa diselamatkan, tetapi bisa ia bisa menceritakannya kepada dunia; kepadamu (Armandio, 2012: 108-109).

\section{Karakter}

Karakter sentral dalam novel Dekat dan Nyaring (2019) adalah Anak Baik. Ekspresi dari pemikirannya yang sederhana sebagai seorang anak kecil dan tanggapan-tanggapan yang muncul dari orang-orang dewasa di sekitarnya menjadi satu kesatuan penggambaran situasi bagi pembaca. Sementara itu, Edi dan Nisbi menjadi karakter utama. Kemunculan Edi di awal cerita dan Nisbi pada pertengahan cerita selalu saling melengkapi dalam menyelesaikan segala macam permasalahan.

Anak Baik merupakan karakter sentral dalam novel Dekat dan Nyaring (2019). Dalam novel tersebut diceritakan bahwa Anak Baik adalah seorang anak kecil yang baru akan memasuki jenjang pendidikan Sekolah Dasar. Karakter Anak Baik digambarkan sebagai seorang anak yang terlahir dengan pemikiran cerdas. Keingintahuan yang tinggi menjadikannya sering bertanya kepada orang-orang di sekitarnya. 
Anak Baik dibesarkan oleh seorang ibu sebab ayahnya telah meninggal sedari ia masih di dalam kandungan. Pada kelanjutan cerita, Anak Baik selalu berharap bahwa ayahnya dapat kembali dan membuat ibunya senang. Ia mencari tahu segala cara dengan segala keterbatasan pemikirannya. Bertanya kepada para orang dewasa di sekitarnya menjadi pilihan utamanya.

"Siapa itu Pak Koksi?" tanya Anak Baik, "Tadi Pak Sam dan Ibu membicarakan Pak Koksi, sepertinya dia orang hebat." "Oh," jawab Sam, "Pak Koksi bisa melakukan apa saja." "Kalau begitu dia bisa menghidupkan Ayah, dong?" Sam dan Nisbi saling berpandangan. "Pak Sam, bukannya tadi sedang cari kucing?" tanya Nisbi, dan seolah mengerti Sam, sekali lagi, membenarkan posisi ikat pinggangnya (Armandio, 2019: 29-30).

Kutipan di atas merupakan rasa penasaran yang pertama kali muncul dalam diri Anak Baik. Ketika itu ia sedang menonton televisi dengan Aziz, anak dari Wak Eli yang menderita keterbelakangan mental. Kemudian setelah Sam pulang, Anak Baik lanjut bertanya kepada Nisbi mengenai siapa itu Pak Koksi. Ibunya yang mengerti bahwa anaknya belum bisa membaca mulai melakukan satu kebohongan dengan membacakan dongeng dari buku yang sama sekali tidak bersangkutan.

"Cerita Orang Patos dan Orang Koksi," potong Nisbi, lalu mulai membuka halaman pertama buku berjudul 'Cara Jitu Menembus Ujian Psikotes dan Tes Akademik SECAPA POLRI'. Nisbi berdeham dua kali, dan berkata bahwa ia akan menceritakan isi buku itu dengan catatan Anak Baik harus berhenti merengek dan Aziz tidak boleh menyela cerita. Anak Baik dan Aziz setuju (Armandio, 2019: 31).

Gambaran cerdas pada karakter Anak Baik menjadikannya berinisiatif untuk menanyakan kebenaran cerita tersebut kepada Wak Eli, Edi, dan juga Kina. Karakter-karakter yang ada dalam cerita saling berhubungan dengan Anak Baik. Oleh karena itu, Anak Baik merupakan karakter sentral.

Novel Dekat dan Nyaring (2019) tidak menceritakan sisi kehidupan yang rinci dari seorang Anak Baik yang semula masih belum bersekolah. Pada pertengahan cerita, melalui keterlibatan karakter lain dengan Anak Baik, terungkap kejujuran yang sedikit dikesampingkan karena tujuan dan desakan tertentu. Di akhir cerita, setelah terjadi suatu kejadian yang sangat ribut, diceritakan Anak Baik yang kembali mengunjungi lingkungan tempat tinggalnya setelah 20 tahun berlalu. Ia telah tumbuh menjadi seorang penulis novel.

ANAK BAIK membuka telapak tangannya dua puluh tahun kemudian. Sebuah sekring. Ia menggenggamnya selama membonceng motor dan baru membukanya setelah motor berhenti di pohon randu di tepi sungai. 
Di taman itu segalanya terlihat baik-baik; cangkang kapuk randu pecah dan tertiup angin, membuat musim salju seolah datang ke negeri tropis (Armandio, 2019: 108).

Edi merupakan salah satu karakter yang selalu muncul di setiap peristiwa di dalam cerita. Di awal sampai akhir kisah yang ada, Edi selalu terlibat di dalamnya. Seperti seorang pahlawan yang selalu semangat dalam menjalani hidup dan menolong orang di sekitarnya. Pemikirannya yang selalu optimis menjadikan Edi secara tidak langsung menyampaikan pesan positif kepada para pembaca.

Edi terengah-engah, berusaha mengatur napas. "Eh, Ed. Kau mungkin bisa membuka warungmu enam belas jam saja," ujar Idris, menunjuk triplek yang dikempit Edi. "Seberapa sering, sih, kau mendapat pelanggan malam-malam?" "Selalu ada jalan lain," jawab Edi, kalimat pamungkas yang selalu muncul tiap kali ada orang yang memaksanya berhenti (Armandio, 2019: 19).

Edi selalu bersikap baik kepada para tetangga yang hanya segelintir tersisa di Gang Patos. Ia tinggal di warung miliknya yang berada di tepi sungai. Di sana, ia menjual berbagai macam hal yang dapat dijual untuk memenuhi kebutuhan hidup, baik itu jujur ataupun setengah jujur.

Kenyataan itu tak membuat Edi putus asa, ia meyakini kalimat kesukaannya setiap kali menghadapi masalah, "Selalu ada jalan lain." Seperti, misalnya, mencincang sanca dan menjualnya sebagai kobra. Ketika sudah berupa daging asap dan minyak, kecuali seorang ilmuwan ahli ular kurang kerjaan, tak ada satu pun yang bisa melihat perbedaannya (Armandio, 2019: 8).

Keadaan hidup yang tidak serba berkecukupan menjadikan Edi jeli dalam menyiasati sesuatu. Selain untuk hidupnya sendiri, Edi juga kerap membantu tetangganya yang lain, Nisbi misalnya. Nisbi memiliki kebutuhan menyekolahkan Anak Baik di Sekolah Dasar tahun depan. Edi memiliki solusi singkatnya.

"Sekarang kita petik daun-daun ini sebanyak-banyaknya." Nisbi berdecak, "Ini penipuan, Ed." "Sedikit saja, Tuhan akan maklum. Ya, kira-kira sampai kau punya cukup modal untuk menjual ganja dengan jujur." "Tak ada urusan dengan Tuhan. Pelangganku jauh lebih penting. Aku membayangkan perasaan mereka jika tahu, Ed. Sepintar apa pun dirimu, mereka lebih pintar lagi buat urusan mabuk. Mereka sudah mengisap ganja sejak SD." (Armandio, 2019: 67). 
Selalu ada ide muncul dari kepala Edi. Karakter Edi dimunculkan sebagai seseorang yang membawa sebuah penyelsaian bagi orang lain di sekitarnya. Edi adalah sosok yang baik hati, meskipun ia juga kesusahan. Kendala perekonomian menjadi permasalahan utama yang tidak dapat terelakkan.

Di seberang sungai Edi batuk sampai terbungkuk-bungkuk. Ia memegangi perutnya, seperti sedang berusaha menahan sesuatu. Nisbi berkali-kali menyemangati Edi, sebab tak banyak yang bisa ia lakukan. Anak Baik membantu ibunya menarik tali, ketika ember sudah dekat, ia meraih ember itu dan mengambil sesuatu di dasar ember. Edi menceburkan diri ke sungai. Anak Baik menggenggam benda di tangannya (Armandio, 2019: 108).

Edi juga turut menyampaikan cerita mengenai Pak Koksi kepada Anak Baik. Nisbi dan Anak Baik selalu dalam rentang jangkauan Edi. Hingga di akhir cerita pun Edi dengan sigap menolong Nisbi dan Anak Baik dari musibah yang menimpa Gang Patos. Hal itu juga membuat dirinya harus berkorban.

Nisbi adalah ibu dari Anak Baik. Seorang janda yang ditinggal mati suaminya sedari Anak Baik masih di dalam kandungan. Sebenarnya, Nisbi juga tidak menginginkan hal itu terjadi. Namun, suaminya membawa pulang wanita simpanannya dan terjadilah sebuah insiden yang membunuh wanita simpanan tersebut beserta suaminya.

Nisbi mengambil pistol dari pinggang suaminya, mengarahkan moncongnya ke dinding mulut. Ia mengusap perutnya yang menggelembung seperti terkena tumor ganas. Suaminya dengan gesit mengambil pistol dari tangan Nisbi lalu, tanpa sempat menarik napas, menembaki karung itu. Tiga tembakan. Suaminya menatap Nisbi, mengucap sesuatu yang tak terpahami oleh Nisbi. Nisbi bisa melihat punggung suaminya yang tegap, dan bagaimana kedua bahu suaminya naik turun dengan cepat sebelum terdengar satu tembakan lagi. Sesuatu yang kental dan anyir mendarat di wajah Nisbi. Nisbi menjatuhkan badan ke kursi, kemudian senyap (Armandio, 2019: 89).

Pada saat kejadian itu terjadi, Nisbi memutuskan untuk memanggil Edi. Seseorang yang dapat diandalkan dalam segala sisi kehidupannya. Edilah yang kemudian mengurus mayat suami Nisbi hingga tidak terlacak lagi. Semua orang di kampung, termasuk polisi, mempercayai perkataan Nisbi bahwa pada suatu malam sekelompok orang menyatroni rumah dan membawa pergi suaminya.

Rumitnya kehidupan sebagai seorang ibu tunggal membuat Nisbi mencari cara untuk bertahan hidup, yaitu dengan berjualan ganja. Anak Baik yang tinggal serumah dengannya tidak mengetahui hal itu. Kepada Anak Baik, Nisbi mengajarkan segala hal baik selayaknya orang tua pada umumnya. 
Nisbi mengeluarkan plastik kecil berisi biji-bijian, memperkenalkan bijibijian itu sebagai Keluarga Ana Mayuri. Anak Baik meletakkan biji di atas kapas basah. Nisbi melingkari kalender dengan spidol merah sambil memuji Anak Baik; ia telah membuat lingkungan yang baik untuk tumbuh kembang Keluarga Maskoki dan Keluarga Ana Mayuri dan, sebagai anak yang baik, ia harus menyayangi makhluk hidup lain seperti ia menyayangi diri sendiri (Armandio, 2019: 23).

Dengan cara seperti itulah, Nisbi mendidik Anak Baik hingga ia dewasa. Nisbi selalu memperjuangkan keberlangsungan hidup mereka dengan caranya. Nisbi ingin berjualan dengan jujur, meskipun barang jualannya berupa ganja. Ketika Edi menawarkan kembang bokor yang dikeringkan sebagai alternatif lain dari ganja, Nisbi selalu menolaknya dengan beradu argumen.

Karakter bawahan dalam novel ini adalah Aziz. Ia adalah anak dari Wak Eli yang memiliki keterbelakangan mental 10 tahun lebih muda dari usia sebenarnya. Dalam novel ini juga terdapat karakter-karakter lain yang masingmasing kemunculannya menyampaikan pesan penulis kepada pembaca. Karakter-karakter tersebut meliputi Wak Eli. Sam, Idris, dan Kina.

Aziz selalu menjadi teman bermain Anak Baik. Dengan lingkungan yang rawan gusur, tidak lagi banyak anak kecil yang tinggal di situ. Aziz cenderung bersifat kekanak-kanakan dan dapat mengimbangi Anak Baik karena masalah mentalnya. Dengan hadirnya karakter Aziz, motif karakter Anak Baik semakin dapat ditampakkan oleh penulis. Apa yang diutarakan oleh Aziz memicu pemikiran Anak Baik beserta opininya terhadap apa yang belum diketahuinya.

"Siapa itu Jackie Chan?" "Polisi, umm," jawab Aziz sambil memainkan ujung pakaiannya dengan jari, "Polisi pertama yang main perosotan dari atas gedung. Syuuut. . . "Kau yakin Jackie Chan polisi yang baik?" Aziz mengangguk keras, "Aku nggak pernah lihat orang sebaik Jackie Chan." "Tapi, gara-gara Pak Sam datang ibuku jadi merusak Keluarga Ana Mayuri." (Amandio, 2019: 25).

Aziz berusia dua puluh tahun dengan usia mentalnya yang baru sepuluh tahun. Kehadiran Aziz diposisikan sebagai seorang anak kecil oleh orang-orang dewasa di sekitarnya. Bahkan ia mencium tangan Kina, Idris, dan Edi saat berpamitan pulang padahal usia Edi masih berkisar dua puluhan. Aziz juga tidak berpikir panjang saat Sam mencoba mengambil kembali pistol miliknya. Ia menganggap itu sebagai sebuah ancaman sehingga pada akhirnya nyawa Aziz melayang.

Munculnya Aziz selalu menjadi perantara kejadian yang dipertanyakan dan digumamkan oleh Anak Baik. Semenjak keterlibatan Anak Baik dengan dongeng-dongeng yang disampaikan oleh Nisbi hingga Kina, Aziz ada sebagai 
karakter bawahan yang melaluinya diperlihatkan pemikiran Anak Baik atau orang dewasa lainnya.

Seperti yang telah penulis sebutkan sebelumnya, selain Aziz terdapat karakter-karakter dalam novel yang melengkapi jalannya cerita. Kina adalah istri Idris. Kina juga tidak memiliki pemikiran sederhana seperti kelihatannya. Sebenarnya, ia adalah seorang penulis yang sedang melakukan sebuah metode penulisan dalam menyusun novelnya. Ia memiliki seorang kenalan bernama Dea yang membantunya memperoleh informasi dari dunia luar. Dea juga seorang penulis yang sebenarnya menentang metode yang tengah dijalani oleh Kina.

"Kau seharusnya bilang kepada mereka bahwa kau merekam dan mencatat obrolan kalian," ujar Dea Anugrah, si pengendara, segera setelah menyamankan bokong di kursi dan melihat Kina meletakkan alat rekam di meja. "Mau sampai kapan kaujadikan mereka seperti tikus lab?" "Berapa kali harus kukatakan sampai kau mengerti? Aku nggak sedang menjadikan mereka bahan eksperimen, ini method writing, aku sedang menjadi mereka. Memangkas jarak dengan mengalami kehidupan kaum miskin kota. Tujuannya jelas, aku ingin menyuarakan penderitaan mereka." (Armandio, 2019: 93).

Dea bukan semata-mata menentang Kina karena ketidaksukaannya terhadap metode penulisan tersebut, melainkan ia ingin menyatakan bahwa sebenarnya itu tidak akan mengubah apa pun. Ia menyarankan kepada Kina untuk menulis jurnal atau esai jika memang ingin mengangkat masalah kaum miskin kota. Selain itu, Dea juga mengatakan bahwa mereka dapat menyelesaikan permasalahan mereka sendiri.

Adanya hal yang ditutup-tutupi oleh masing-masing karakter menyampaikan pesan dari penulis kepada pembaca. Pesan yang tersirat tersebut akan dapat diapresiasi oleh pembaca sesuai dengan tingkat pemikiran setiap individu. Keseharian yang diperlihatkan oleh karakter utama dan bawahan cenderung sederhana. Namun, dibalik kesederhanaan tersebut, sebenarnya mereka memiliki kemampuan berpikir dan bertahan hidup yang cukup rumit.

\section{Hubungan Alur dan Karakter}

Alur yang terdiri dari tahap awal, tengah, dan akhir menjadi sebuah kesatuan yang utuh jika terdapat unsur lain di dalamnya. Salah unsur yang berhubungan dengan alur adalah karakter. Karakter adalah tokoh di dalam cerita yang mengalami kehidupan di dunianya.

Pada tahap awal disebutkan bahwa karakter Edi adalah seorang lelaki yang tinggal di seberang sungai yang memisahkan Gang Patos dengan Permata Permai Residence. Ia membuka warung dengan segala kemampuannya merakit alat-alat buatannya sendiri sebagai media pengasapan daging ular yang ia jual kepada para pelanggannya. Karakter yang ada dalam novel Dekat dan Nyaring 
(2019) tidak hanya Edi saja, melainkan terdapat karakter-karakter lain di setiap perkembangan alurnya.

Tahap tengah menceritakan tokoh Nisbi, Anak Baik, Aziz, Sam, Wak Eli, Idris, dan Kina. Mereka juga tinggal di wilayah yang sama, yaitu Gang Patos. Setiap karakter memiliki kisah masing-masing yang dikembangkan oleh pengarang melalui adanya alur. Peristiwa terjadi secara runtut sehingga dapat dipahami oleh pembaca. Jika peristiwa yang disuguhkan oleh pengarang terkesan melompat-lompat seperti alur campuran, akan tetap ada kesinambungan melalui pengantar dalam bentuk lain.

Alur tahap akhir menyajikan sisi di balik kehidupan karakter yang sebenarnya. Pengarang sengaja menguak kehidupan asli karakter melalui narasi atau siratan dialog antarkarakter. Apa yang ingin ditampilkan oleh pengarang tidak selalu disajikan secara langsung. Hubungan alur dan karakter sangat erat. Tanpa adanya karakter, alur tidak dapat berkembang. Hal ini dikarenakan tidak adanya konflik yang muncul.

\section{SIMPULAN}

Terdapat hubungan erat antara alur dan karakter. Hubungan tersebut berkaitan dengan konflik dan jalan cerita yang ditimbulkan. Tanpa adanya karakter, alur tidak dapat berkembang. Hal ini dikarenakan tidak adanya konflik yang muncul. Bagian karakter yang kosong akan merusak keseimbangan cerita. Begitu pula sebaliknya. Jika tidak ada alur, karakter hanya akan diam di tempat. Karakter bisa saja ada, tetapi ia tidak memiliki jalan cerita yang akan membawanya pada imajinasi sebuah karya sastra.

\section{DAFTAR PUSTAKA}

Armandio, S. (2019). Dekat dan Nyaring. Depok: Banana.

Febriana, T.A. (2018). Analisis Unsur Intrinsik (Tokoh, Alur dan Latar) Menggunakan Pendekatan Saintifik pada Novel 9 Summers 10 Autumns Karya Iwan Setyawan untuk Siswa SMP Budi Mulia Minggir Kelas VIII Semester II. Skripsi. Yogyakarta: Universitas Sanata Dharma.

Prihantoro, D. (2008). Analisis Struktural Novel Towards Zero karya Agatha Christie serta Implementasinya dalam Pembelajaran Sastra di SMK. Skripsi. Yogyakarta: Universitas Sanata Dharma.

Sariningsih, S. (2011). Adaptasi Film ke Novel Brownies: Analisis Strukturalisme Robert Stanton. Skripsi. Surakarta: Universitas Sebelas Maret.

Stanton, R. (2012). Teori Fiksi Robert Stanton. Yogyakarta: Pustaka Pelajar.

Teeuw, A. (1984). Sastra dan Ilmu Sastra: Pengantar Teori Sastra. Jakarta: Dunia Pustaka Jaya. 
Tuslianingsih. (2010). Analisis Unsur Intrinsik Novel Rahasia Meede Karya E.S. Ito dan Novel The Da Vinci Code Karya Dan Brown: Sebuah Perbandingan. Skripsi. Jakarta: Universitas Indonesia.

Wahyuni, E. (2017). Analisis Unsur Intrinsik dan Ekstrinsik Novel Surat Kecil untuk Tuhan Karya Agnes Davonar sebagai Sumbangan Materi bagi Pengajaran Sastra. Skripsi. Palembang: Universitas Muhammadiyah Palembang.

Wellek, R. dan Warren, A. (1990). Teori Kesusastraan. Jakarta: Gramedia.

Widyawati, A. (2016). Cerita Anak Fabel pada Harian Kompas tahun 2015: Kajian Strukturalisme Robert Stanton. Skripsi. Surakarta: Universitas Sebelas Maret. 